\title{
Molecular Identification of Similar Species of the Genus Biomphalaria (Mollusca: Planorbidae) Determined by a Polymerase Chain Reaction-Restriction Fragment Length Polymorphism
}

\author{
Roberta Lima Caldeira, Teofânia HDA Vidigal*, Sônia Torquato Paulinelli, \\ Andrew JG Simpson**, Omar S Carvalho/ ${ }^{+}$
}

\begin{abstract}
Centro de Pesquisas René Rachou-Fiocruz, Av. Augusto de Lima 1715, 31190-002 Belo Horizonte, MG, Brasil *Instituto de Ciências Biológicas, UFMG, Belo Horizonte, MG, Brasil **Laboratório de Genética de Câncer, Instituto Ludwig de Pesquisas sobre o Câncer, São Paulo, SP, Brasil
\end{abstract}

The freshwater snails Biomphalaria straminea, B. intermedia, B. kuhniana and B. peregrina, are morphologically similar; based on this similarity the first three species were therefore grouped in the complex B. straminea. The morphological identification of these species is based on characters such as vaginal wrinkling, relation between prepuce: penial sheath:deferens vas and number of muscle layers in the penis wall. In this study the polymerase chain reaction restriction fragment length polymorphism technique was used for molecular identification of these molluscs. This technique is based on the amplification of the internal transcribed spacer regions ITS1 e ITS2 of the ribosomal RNA gene and subsequent digestion of these fragments by restriction enzymes. Six enzymes were tested: Dde I, Mnl I, Hae III, Rsa I, Hpa II e Alu I. The restriction patterns obtained with DdeI presented the best profile for separation of the four species of Biomphalaria. The profiles obtained with all the enzymes were used to estimate the genetic distances among the species through analysis of common banding patterns.

Key words: Biomphalaria straminea - Biomphalaria kuhniana - Biomphalaria intermedia - Biomphalaria peregrina - snails - polymerase chain reaction - restriction fragment length polymorphism

Schistosomiasis mansoni is endemic in several countries of the Americas and Africa (WHO 1993). It is caused by Schistosoma mansoni (Sambon 1907), the intermediate hosts of which are freshwater snails of the genus Biomphalaria. Ten species and one subspecies of this genus are known in Brazil (Paraense 1975, 1981, 1984, 1988), of which only B. glabrata, B. tenagophila e B. straminea have been found with natural infections. Two other species (B. amazonica and B. peregrina), can also be infected experimentally and are considered to be potential hosts of the trematode (Corrêa \& Paraense 1971, Paraense 1973).

The specific identification of $B$. straminea, $B$. kuhniana, $B$. intermedia and B. peregrina is based on very similar morphologically characters. Because of this similarity, Paraense (1988) grouped the first three species in a complex named $B$.

Work partially supported by Fapemig and PIBIC/Fiocruz. ${ }^{+}$Corresponding author. Fax: +55-31-295.3115. E-mail: omar@netra.cpqrr.fiocruz.br

Received 4 May 1998

Accepted 31 August 1998 straminea. Hofman (1987) and Pointier et al. (1993) used isoenzymatic techniques for the differentiation of some of these species. However Steindel et al. (1994) pointed out that this technique had certain limitations, such as the requirement for large quantities of biological material, and the small number of loci examined consequently providing relatively little information at the intraspecific level.

Knight et al. (1991), used RFLP (restriction fragment length polymorphism) in the molecular differentiation of species of the genus Biomphalaria, while Vidigal et al. (1996) and Pires et al. (1997) utilized LS-PCR (low stringency polymerase chain reaction) for identification of species of this genus. Langand et al. (1993) and Vidigal et al. (1994) used AP-PCR (arbitrarily primed- polymerase chain reaction ) to study genetic variability of Bulinus and Biomphalaria respectively.

Hope and McManus (1994) analyzed restriction polymorphisms in the internal transcribed spacer region of ribosomal RNA gene generated through the polymerase chain reaction (PCRRFLP), to distinguish subespecies of Oncomelania hupensis. This technique has also been used for the differentiation of Bulinus (Stothard et al. 
1996, Stothard \& Rollison 1997) and Biomphalaria (Vidigal et al. 1998).

We here describe the identification of $B$. straminea, B. kuhniana, B. intermedia and $B$. peregrina using classical morphological identification as well as the PCR-RFLP technique in order to differentiate molecularly these species and to estimate the genetic distances among them.

\section{MATERIALS AND METHODS}

Snails populations - The snail species used are listed in Fig. 1, together with their distribution in Brazil (Paraense 1986, 1988, Carvalho et al. 1994, 1997). Populations of snails were collected in the field, except B. straminea from Paraná, Bahia and Piauí specimens which were obtained from the Departamento de Malacologia of Instituto Oswaldo Cruz, Rio de Janeiro. All field-collected specimens were examined for $S$. mansoni and found to be negative. The snails were killed, fixed (Deslandes 1951, Paraense 1976) and the foot of each specimen removed for subsequent DNA extraction.

Selection of the restriction enzymes was done using three specimens from each of the following species and localities: B. kuhniana from Tucuruí (PA); B. straminea from Belém (PA), Monte Carmelo (MG) and Guaíra (PR); B. intermedia from Jales (SP), Paulo Farias (SP) and Planura (MG); and B. peregrina from Taim (RS), Guimarania (MG) and Alfenas (MG).

DNA extraction - Total DNA was extracted from the foot of each snail as described by Vidigal et al. (1994) and Steiner et al. (1995) with some modifications. The foot of each snail was lysed mechanically with $200 \mathrm{ml}$ of $50 \mathrm{mM}$ Tris- $\mathrm{HCl}$ at $\mathrm{pH} 8.0,100$ $\mathrm{mM} \mathrm{NaCl}, 50 \mathrm{mM}$ EDTA and $0.5 \%$ SDS then incubated overnight at $37^{\circ} \mathrm{C}$ with $50 \mathrm{mg} / \mathrm{ml}$ proteinase K. Following incubation, $200 \mathrm{ml}$ of a buffer solution containing $10 \mathrm{mM}$ Tris- $\mathrm{HCl}$ and $2.5 \mathrm{mM}$ EDTA at $\mathrm{pH} 8.0$ and $1 \%$ polyvinyl-polypyrrolidone (PVPP, insoluble in water) was added and incubated for 20 min at $95^{\circ} \mathrm{C}$. This solution was subsequently placed in ice for $5 \mathrm{~min}$, then centrifuged at 14,000 rpm for 10 min. After centrifugation the DNA was transferred to tubes of $1.5 \mathrm{ml}$ and precipitated by the addidtion of $0.1 \mathrm{vol}$. Na acetate ( $3 \mathrm{M}, \mathrm{pH} 7)$ and 3 vol. absolute ethanol. The precipitated DNA was washed in $70 \%$ ethanol, resuspended in $20 \mathrm{ml}$ water and cooled to $-20^{\circ} \mathrm{C}$.

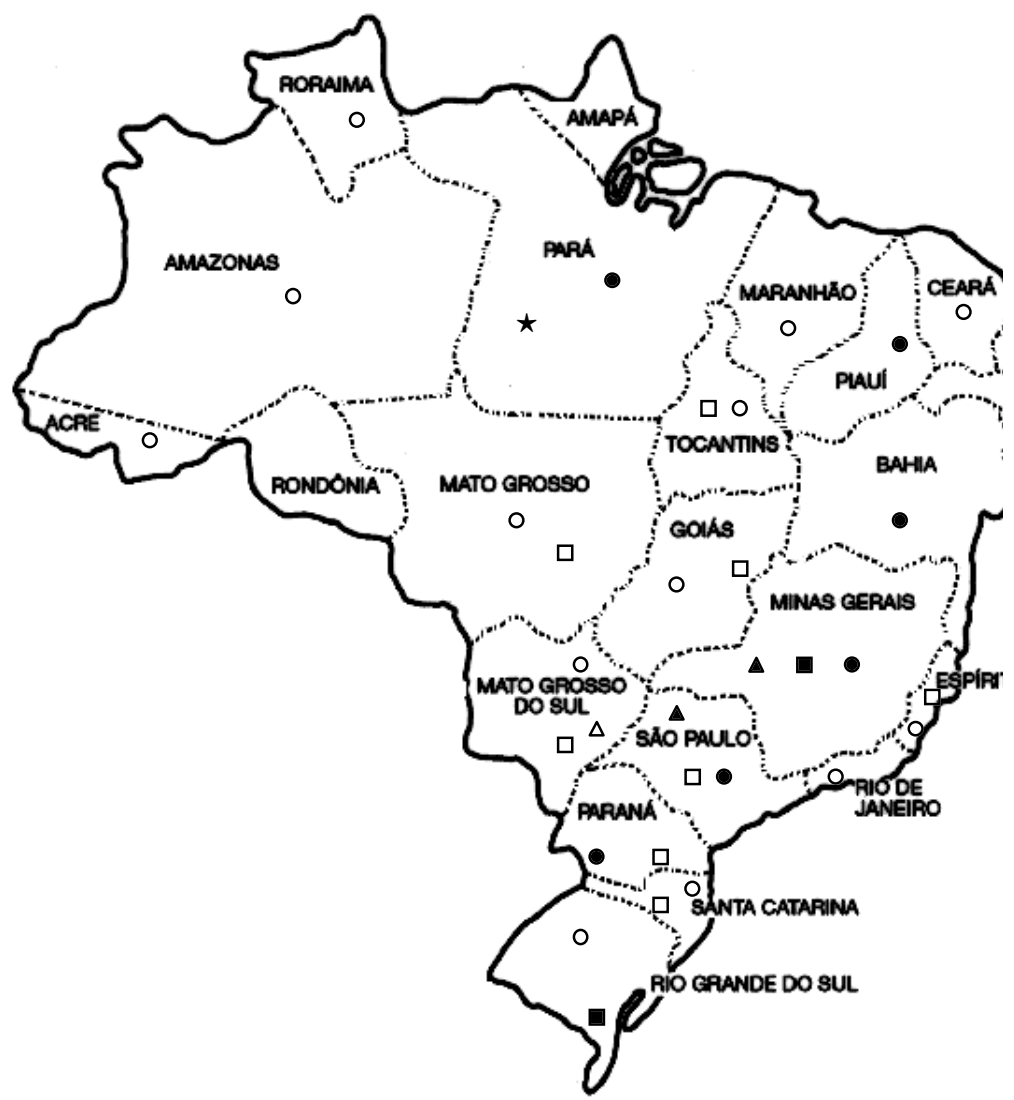

Fig. 1: geographical distribution of four Biomphalaria species. (๑) Biomphalaria straminea; $(\boldsymbol{\square})$ B. peregrina; $(\mathbf{\Delta})$ B. intermedia;

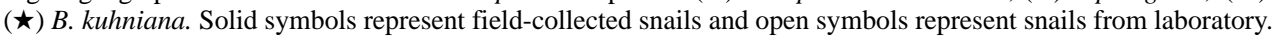


The rDNA-ITS amplification - The entire ITS (which includes the 5.8S rDNA gene together with the flanking ITS1 and ITS2 spacers) was amplified using the primers ETTS2 (5/-TAACAAGG TTTCCGTAGGTGAA-3/) and ETTS1 (5/-TGC TTAAGTTCAGCGGGT-3/) anchored respectively in the conserved extremities of the $18 \mathrm{~S}$ and $28 \mathrm{~S}$ ribosomal genes (Kane \& Rollinson 1994). The PCR amplification was undertaken in a volume of: $10 \mathrm{ml}$ consisting of: 1-10 ng of template DNA, $10 \mathrm{mM}$ Tris$\mathrm{HCl}, \mathrm{pH} 8.5,200 \mathrm{mM}$ each dNTP, $1.5 \mathrm{mM} \mathrm{MgCl}_{2}$, $0.8 \mathrm{U}$ of Taq DNA polymerase (Cenbiot, RS, Brazil), $50 \mathrm{mM} \mathrm{KCl}$, together with $1.0 \mathrm{pmol}$ of each primer. The reactions were covered with a drop of mineral oil and subjected to the following cycle program: initial denaturation step for $5 \mathrm{~min}$ at $95^{\circ} \mathrm{C}$, and then 32 cycles with: annealing of $54^{\circ} \mathrm{C}$ for 1 min, extension at $72^{\circ} \mathrm{C}$ for $2 \mathrm{~min}$, denaturation at $95^{\circ} \mathrm{C}$ for $45 \mathrm{sec}$ and a final extension step at $72^{\circ} \mathrm{C}$ for $5 \mathrm{~min}$. A negative control (no template DNA) was included in all experiments. Three ml of the amplification products were visualised on $0.8 \%$ ethidium bromide stained agarose gels to check the quality of amplification. The remaining $7 \mathrm{ml}$ were mixed with $93 \mathrm{ml}$ of water and divided into $10 \mathrm{ml}$ aliquots for subsequent enzyme digestion.

RFLP analysis - To evaluate possible enzymes that might yield informative RFLP of the ITS regions, six restriction enzymes (Amersham Life Science) were used: four base cutters AluI, HaeIII, HpaII, RsaI, five base cutters DdeI and 11 base cutters MnlI. One ml of each enzyme (10-12 units) was used for each digestion reaction, together with $1.2 \mathrm{ml}$ of the respective enzyme buffer and $10 \mathrm{ml}$ of the diluted amplification product in a final volume of $12.2 \mathrm{ml}$. The digestion was performed for $3.5 \mathrm{hr}$ at $37^{\circ} \mathrm{C}$, and products were separated on $6 \%$ silver stained polyacrylamide gels (Santos et al. 1993, Sanguinetti et al. 1994) after phenol/chloroform extraction to remove protein. The results were recorded with Polaroid film 667 (Sigma Albans, UK). A control for the activity of each enzyme was performed by digesting $150 \mathrm{ng}$ of pUC18 simultaneously with the samples being evaluated.

Quantitative analysis of restriction profiles The bands observed on each lane were compared with all the other lanes of the same gel. A matrix of taxon/character was constructed based on the presence/absence of each band. The most easily distinguishable bands were considered for analysis. The data obtained were analysed with TREECON for Windows (Version 1.2 - Van de Peer $\&$ De Wachter 1994) and NTSYS-PC (Version 1.6 - Rohlf 1990). The genetic distance was calculated using the coefficient of Nei and $\mathrm{Li}$ (1979). These data were clustered with Neighbor-joining - NJ (Saitou \& Nei 1987, Studier \& Keppler 1988) and used for the construction of tree of the genetic distance. The reliability of the $\mathrm{NJ}$ trees is assessed by the bootstrap method (Felsenstein 1985) with 1,000 pseudoreplications. The percentage of shared bands was calculated using the similarity coefficient of Dice (Dice 1945). These data were clustered with UPGMA, unweighted pair group method analysis (Sneath \& Sokal 1962) and used for the construction of tree of the similarity. The average similarity among all the individuals in the group was calculated and marked on the tree as the phenon line. Divergence below the phenon line indicates separation of distinct groups. The comparison was made among individual snails of the same species from different localities and among snails from different species.

\section{RESULTS}

RFLP analysis - DNA amplification with the ETTS1 and ETTS2 primers generated a fragment of approximately $1.300 \mathrm{pb}$. Among the enzymes used, Dde I presented the best profile for the separation of the snail species (Fig. 2). The enzyme $R s a$ I presented the same profile for B. straminea and B. intermedia (data not shown), while the remaining enzymes presented a polymorphic profile for B. peregrina (Fig. 3).

In order to confirm the reproducibility of the profiles obtained for Dde I two samples were used from each locality, as well as additional specimens from the following species and localities: $B$. straminea from Picos (PI), Varzea do Porto (BA) and Icém (SP) and $B$. intermedia from Tupaciguara (MG) (data not shown).

Quantitative analysis of restriction profiles The trees were constructed using 79 bands produced by six enzymes, reflecting the genetic distance (Fig. 5a) and similarity (Fig. 5b) among the 12 examples of the four snail species. The genetic distance matrix is shown in the Fig. 4. The bootstrap methods showed that these clades are confirmed with high statistical reliability. Intraespecific distance was observed only among specimens of $B$. peregrina. The degree of intraspecific similarity was $100 \%$ for $B$. kuhniana, B. intermedia, $B$. straminea and $70 \%$ for $B$. peregrina. The mean percentage of bands shared among all the possible pairs was $44 \%$, represented in the dendrogram by the dotted dividing line.

\section{DISCUSSION}

The separation of $B$. straminea, B. kuhniana, B. intermedia and B. peregrina (Paraense 1975, 1988) is based on subtle morphological differences in characters such as the degree of wrinkling of the vaginal wall (absent in B. peregrina, intermediate in B. kuhniana and B. intermedia and con- 


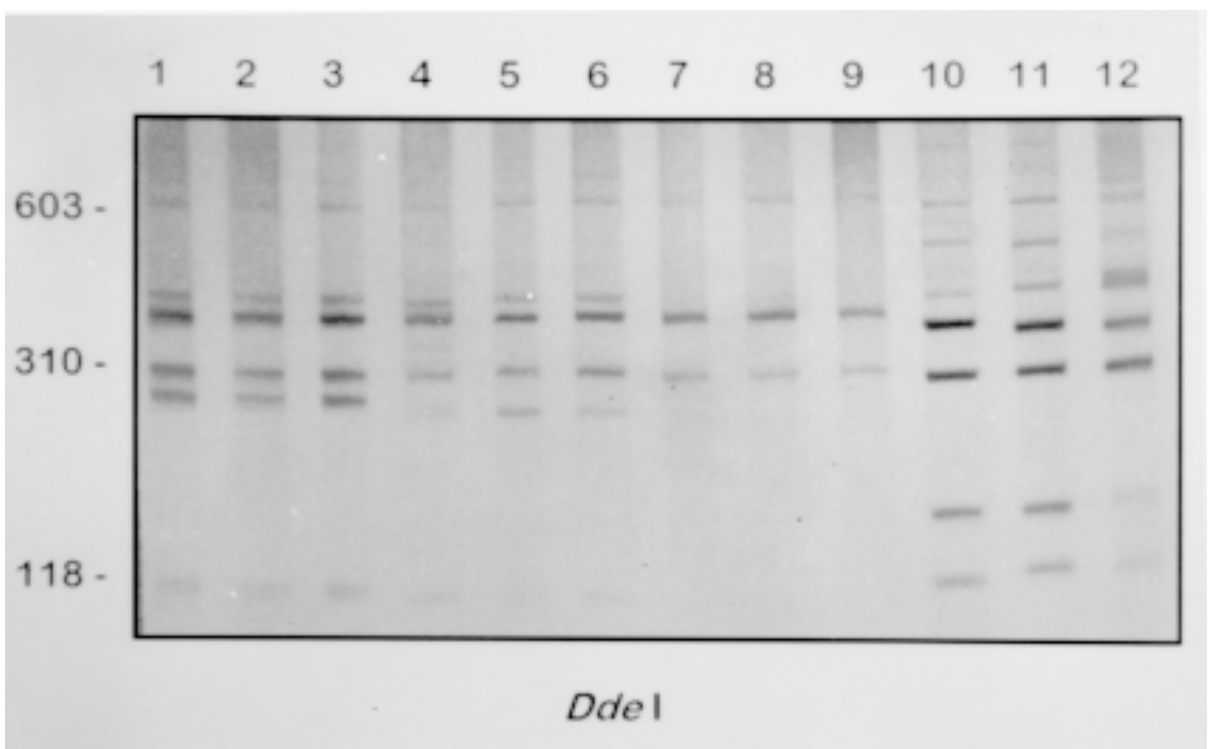

Fig. 2: $6 \%$ silver stained polyacrylamide gels showing the RFLPs profiles obtained following the digestion of the rRNA ITS with DdeI. Snail specimens are: lane 1, 2 and 3 Biomphalaria kuhniana from Tucuruí (PA); lane 4, B. straminea from Belém (PA); lane 5, B. straminea from Monte Carmelo (MG); lane 6, B. straminea from Guaíra (PR); lane 7, B. intermedia from Jales (SP); lane 8, B. intermedia from Paulo Farias (SP); lane 9, B. intermedia from Planura (MG); lane 10, B. peregrina from Taim (RS); lane 11, $B$. peregrina from Guimarania (MG); lane 12, B. peregrina from Alfenas (MG). Molecular size markers are shown in the figure.

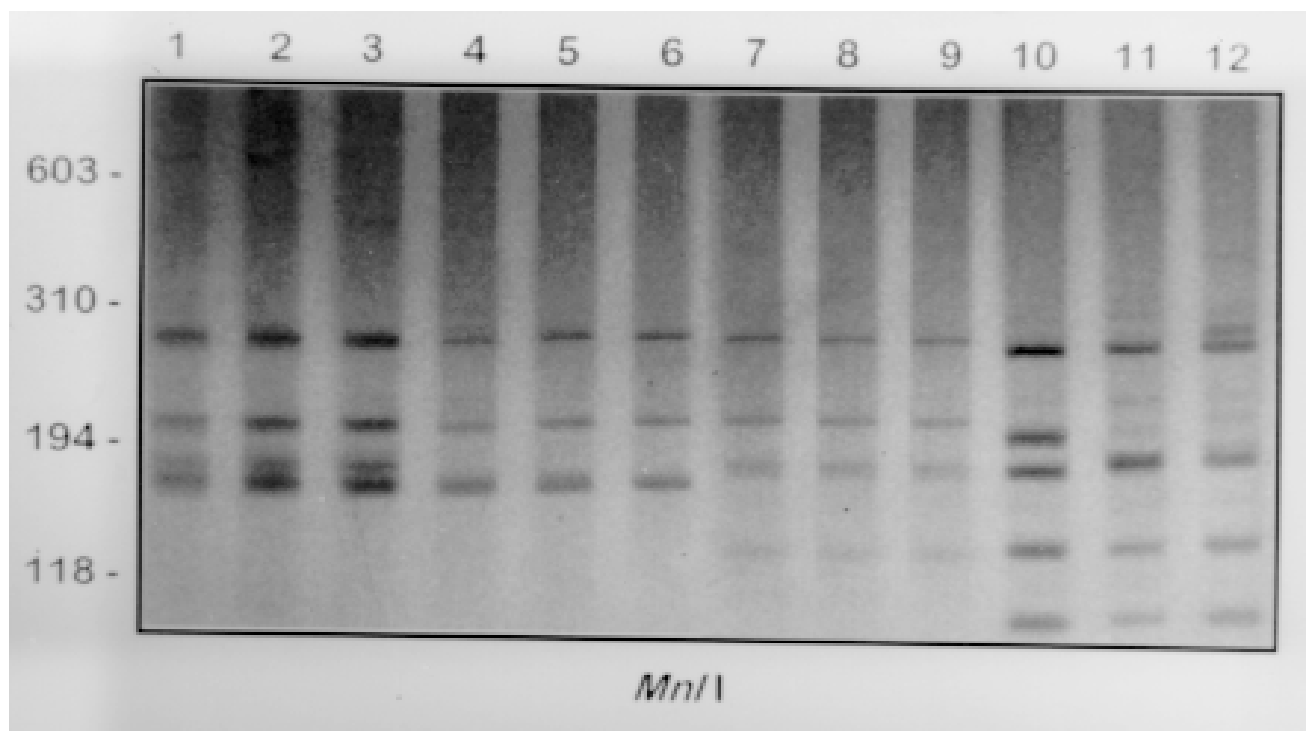

Fig. 3: $6 \%$ silver stained polyacrylamide gels showing the RFLPs profiles obtained following the digesting of the rRNA ITS with Mnl I. Snail specimens are: lane 1, 2 and 3 B. kuhniana from Tucuruí (PA); lane 4, B. straminea from Belém (PA); lane 5, $B$. straminea from Monte Carmelo (MG); lane 6, B. straminea from Guaíra (PR); lane 7, B. intermedia from Jales (SP); lane 8, B. intermedia from Paulo Farias (SP); lane 9, B. intermedia from Planura (MG); lane 10, B. peregrina from Taim (RS); lane 11, $B$. peregrina from Guimarania (MG); lane 12, B. peregrina from Alfenas (MG). Molecular size markers are shown in the figure.

spicuous in B. straminea) and the diameter of the median portion of the penis sheath (in B. peregrina this is greater than the diameter of the vas deferens, while in the other species the diameters are equal). In addition, $B$. straminea has three muscle layers in the wall of the penis (longitudinal, oblique and circular), differing from B. kuhniana, $B$. intermedia and $B$. peregrina that have only two (longitudinal and circular) (Paraense 1975, 1988). The separation of these species is further com- 


\begin{tabular}{|c|c|c|c|c|c|c|c|c|c|c|c|c|}
\hline & B.k.1 & B.k.2 & B.k.3 & B.s. 1 & B.s. 2 & B.s. 3 & B.i.1 & B.i. 2 & B.i.3 & B.p.1 & B.p.2 & B.p.3 \\
\hline B.k.1 & 0.00 & 0.00 & 0.00 & 0.58 & 0.58 & 0.58 & 0.80 & 0.80 & 0.80 & 0.96 & 0.97 & 0.99 \\
\hline B.k.2 & 0.00 & 0.00 & 0.00 & 0.58 & 0.58 & 0.58 & 0.80 & 0.80 & 0.80 & 0.96 & 0.97 & 0.99 \\
\hline B.k.3 & 0.00 & 0.00 & 0.00 & 0.58 & 0.58 & 0.58 & 0.80 & 0.80 & 0.80 & 0.96 & 0.97 & 0.99 \\
\hline B.s.1 & & & & 0.00 & 0.00 & 0.00 & 0.82 & 0.82 & 0.82 & 0.98 & 0.99 & 1.0 \\
\hline B.s. 2 & & & & 0.00 & 0.00 & 0.00 & 0.82 & 0.82 & 0.82 & 0.98 & 0.99 & 1.0 \\
\hline B.s. 3 & & & & 0.00 & 0.00 & 0.00 & 0.82 & 0.82 & 0.82 & 0.98 & 0.99 & 1.0 \\
\hline B.i.1 & & & & & & & 0.00 & 0.00 & 0.00 & 0.90 & 0.91 & 0.93 \\
\hline B.i.2 & & & & & & & 0.00 & 0.00 & 0.00 & 0.90 & 0.91 & 0.93 \\
\hline B.i.3 & & & & & & & 0.00 & 0.00 & 0.00 & 0.90 & 0.91 & 0.93 \\
\hline B.p.1 & & & & & & & & & & 0.00 & 0.68 & 0.64 \\
\hline B.p. 2 & & & & & & & & & & & 0.00 & 0.59 \\
\hline B.p. 3 & & & & & & & & & & & & 0.00 \\
\hline
\end{tabular}

Fig. 4: genetic distance matrix. The letters refer to species and the localities from which the snails originate. Abreviations used in the figure: B.k.1, B.k.2 and B.k.3 = Biomphalaria kuhniana from Tucuruí (PA); B.s.1 = B. straminea from Guaíra (PR); B.s.2=B. straminea from Monte Carmelo $(\mathrm{MG})$; B.s. $3=$ B. straminea from Belém (PA); B.i.1 = B. intermedia from Planura $(\mathrm{MG}) ; \mathrm{B} . \mathrm{i} .2=B$. intermedia from Paulo Farias (SP); B.i.3 = B. intermedia from Jales (SP); B.p.1 = B. peregrina from Alfenas $(\mathrm{MG}) ; \mathrm{B} . \mathrm{p} .2=B$. peregrina from Guimarania (MG); B.p. $3=$ B. peregrina from Taim (RS).

A $\stackrel{\text { distance } 0.1}{\longmapsto}$

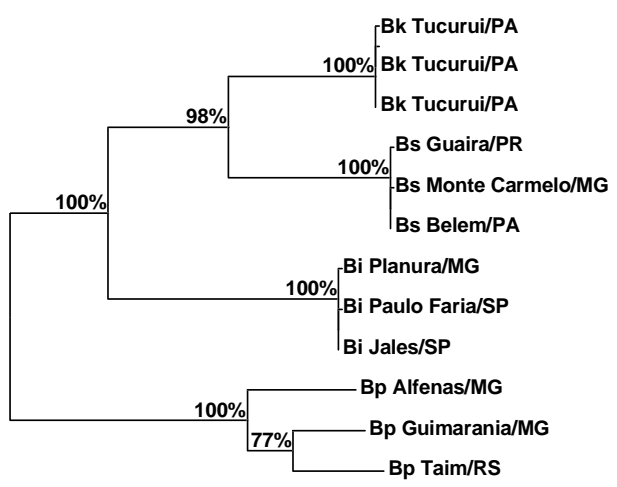

B

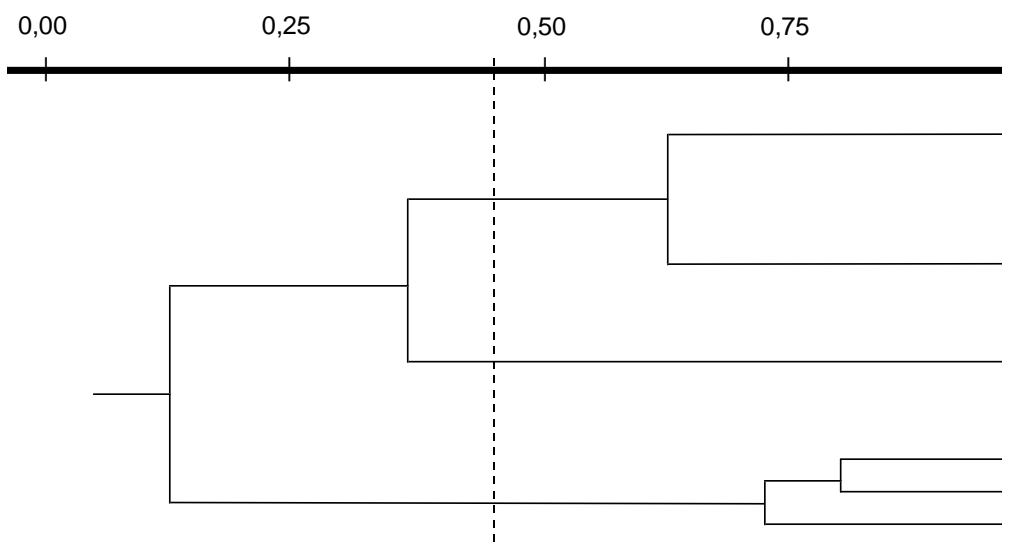

Fig. 5a: neighbor-joining tree unrooted of Biomphalaria kuhniana, B. straminea, B. intermedia and B. peregrina constructed using the PCR-RFLPs profiles produced with all enzymes used. The numbers are bootstrap percent values based on 1,000 pseudoreplications. Fig. 5b: UPGMA tree of B. kuhniana, B. straminea, B. intermedia and B. peregrina constructed using the PCR-RFLPs profiles produced with all enzymes used. The numbers shown on top are indices of similarity. The vertical line is the phenon line, which shows the average level of similarity between all of the pair samples analyzed. 
plicated by the high genetic variability observed in the genus Biomphalaria and by the small size of the specimens, making dissection and perception of morphological differences difficult (Paraense 1975, Vidigal et al. 1994).

Pointier et al. (1993), using isoenzyme technique observed that $B$. kuhniana presented slight genetic differences in relation to $B$. straminea, concluding that these differences could be attributed to geographical isolation or due to the fact that $B$. straminea was a complex of species rather than a single taxonomic entity. In this study, a similarity of $64 \%$ and a smaller genetic distance $(0.58)$ between the two species was found supporting the results of the previous authors.

To confirm our results, two cluster analysis methods were used, the UPGMA which assume that all lineages (OTU's) have diverged equal amounts and the NJ wich is conceptually related to traditional cluster analysis, but removes the assumption that all lineages have diverged equal amounts (Swofford et al. 1996).

The trees produced by these methods showed the same topology with the formation of three distinct groups: the first clustered $B$. straminea and $B$. kuhniana species, the second consisted by only specimens of $B$. intermedia and the third only by specimens of $B$. peregrina. However, $B$. intermedia is more related to $B$. straminea and $B$. kuhniana than to $B$. peregrina. This molecular results reinforces data of Paraense (1988) which grouped $B$. straminea $B$. kuhniana and $B$. intermedia in B. straminea complex.

The intraspecific genetic distance seen in $B$. peregrina may be attributed to its dispersion in the world, deriving its scientific name "from the latin peregrinus, meaning wanderer, in reference to its wide geographical distribution " (Paraense 1975). The sequences of ITS regions will be analyzed in the future to better understand the intraspecific polymorphism of this species.

The PCR-RFLP technique, using the ITS region fragment restricted by the Dde I enzyme, will be an auxiliar tool for the identification of morphologically similar species such as the members of these studies.

\section{ACKNOWLEDGMENTS}

To Dr W Lobato Paraense, Departamento de Malacologia, Instituto Oswaldo Cruz (RJ) for providing material and confirming the identification of $B$. kuhniana; to Dr Jorge Travassos and Dr Izabel de Carvalho Rodrigues, Instituto Evandro Chagas (Belém, PA); to Ildenê CS Gomes, Fundação Nacional de Saúde (Tucuruí, Pará); to Horácio MS Teles (São Paulo, SP) and Sirle Abdo Solloum Scandar (São José do Rio Preto, SP), Superiendência de Controle de Endemias; to Izabel Michelin Nunes, Fundação Nacional de Saúde (Porto Alegre, RS) for facilities for field work.

\section{REFERENCES}

Carvalho OS, Massara CL, Neto HVS, Alvarenga AG, Vidigal THDA, Guerra HL, Santos MA, Chaves A, Katz N 1994. Schistosomiasis mansoni in the Region of the Triângulo Mineiro, State of Minas Gerais, Brazil. Mem Inst Oswaldo Cruz 89: 509-512.

Carvalho OS, Massara CL, Neto HVS, Guerra HL, Caldeira RL, Mendonça CLF, Vidigal THDA, Chaves A, Katz N 1997. Reavaluation of non-endemic schistosomiasis areas in Minas Gerais state (Brazil) II. Alto Paranaíba. Mem Inst Oswaldo Cruz 92: 141-142.

Corrêa LR, Paraense WL 1971. Susceptibility of Biomphalaria amazonica to infection with two strains of Schistosoma mansoni. Rev Inst Med Trop São Paulo 13: 387-390.

Deslandes N 1951. Técnica de dissecação e exame de planorbídeos. Rev Serv Espec Saúde Públ 4: 371382.

Dice LR 1945. Measures of the amount of ecological association between species. Ecology 26: 297-302.

Felsenstein J 1985. Confidence limits on phylogenies: na approach using the bootstrap. Evolution 39: 783-391.

Hofman PRP 1987. Aspectos da Biologia e do Polimorfismo Enzimático em Três Espécies do Gênero Biomphalaria, Thesis, Universidade Federal de São Paulo, São Paulo, 117 pp.

Hope M, McManus DP 1994. Genetic variations in geographically isolated populations and subspecies of Oncomelania hupensis determined by a PCR-based RFLP method. Acta Tropica 57: 75-82.

Kane RA, Rollison D 1994. Repetitive sequences in the ribosomal DNA internal transcribed spacer of Schistosoma haematobium group species based on random amplified polymorfphic DNA. Int J Parasitol 24: 285-290.

Knight M, Brindley PJ, Richards CS, Lewis FA 1991. Schistosoma mansoni: use of a cloned ribosomal RNA gene probe to detect restriction fragment length polymorphism in the intermediate host Biomphalaria glabrata. Exper Parasitol 73: 285-294.

Langand J, Barral V, Delay B, Jourdane J 1993. Detection of genetic diversity within snail intermediate hosts of the genus Bulinus by using random amplified polymorphic DNA markers (RAPDs). Acta Tropica 55: 205-215.

Nei M, Li WH 1979. Mathematical model for studying genetic variation in terms of restriction endonucleases. Proc Natl Acad Sci USA 76: 5269-5273.

Paraense WL 1973. Susceptibility of Biomphalaria peregrina from Brazil and Ecuador to two strains of Schistosoma mansoni. Rev Inst Med Trop São Paulo 15: 127-130.

Paraense WL 1975. Estado atual da sistemática dos planorbídeos brasileiros. Arq Mus Nac 55: 105-128.

Paraense WL 1976. A natural population of Helisoma duryi in Brazil. Malacology 15: 360-376.

Paraense WL 1981. Biomphalaria occidentalis sp.n. from South America (Mollusca: Basommatophora: Pulmonata). Mem Inst Oswaldo Cruz 76: 199-211.

Paraense WL 1984. Biomphalaria tenagophila guaibensis sp.n. from southern Brazil and Uruguay 
(Pulmonata:Planorbidae). I. Morphology. Mem Inst Oswaldo Cruz 79: 465-469.

Paraense WL 1986. Distribuição dos caramujos no Brasil, p. 117-128. In FA Reis et al., Modernos Conhecimentos sobre a Esquistossomose Mansônica, Academia Mineira de Medicina, Belo Horizonte, MG.

Paraense WL 1988. Biomphalaria kuhniana (Clessin, 1883), planorbid mollusc from South America. Mem Inst Oswaldo Cruz 83: 1-12.

Pires ERC, Vidigal THDA, Teles HMS, Simpson AJG, Carvalho OS 1997. Specific identification of Biomphalaria tenagophila and Biomphalaria occidentalis populations by the low stringency polymerase chain reaction. Mem Inst Oswaldo Cruz 92: 101-106.

Pointier JP, Paraense WL, Pernot AF, Delay B 1993. Biomphalaria straminea: species or complex of species? p. 53. Abstracts 4th International Symposium on Schistosomiasis.

Saitou N, Nei M 1987. The neighbor-joining method: a new method for reconstructing phylogenetic trees. Mol Biol Evol 4: 406-426.

Sanguinetti CJ, Neto ED, Simpson AJG 1994. Rapid silver staining and recovery of PCR products separated on polyacrylamide gels. Biotechniques 17: 915918.

Santos FR, Pena SDJ, Epplen TJ 1993. Genetic populational study of an Y-linked tetranucleotide repet DNA polymorphism. Human Genetics 90: 655-656.

Sneath PHA, Sokal RR 1962. Numerical taxonomy. Nature 193: 855-860.

Steindel M, Neto ED, Pinto CJC, Grisard EC, Menezes CLP, Murta SMF, Simpson AJG, Romanha AJ 1994. Ramdomly amplified polymorphic DNA (RAPD) and isoenzyme analysis of Trypanosoma rangeli strains. J Euk Microbiol 41: 261-267.

Steiner JJ, Poklemba CJ, Fjellstrom RG, Elliot LF 1995. A rapid one-tube genomic DNA extraction process for PCR and RAPD analyses. Nucleic Acids Research 23: 2569-2570.

Stothard JR, Hughes S, Rollinson D 1996. Variation within the internal transcribed spacer (ITS) of ribossomal DNA genes of intermediate snail hosts within the genus Bulinus (Gastropoda: Planorbidae). Acta Tropica 61: 19-29.

Stothard JR, Rollinson D 1997. Molecular characterization of Bulinus globosus and B. nasutus on Zanzibar, and an investigation of their roles in the epidemiology of Schistosoma haematobium. Trans R Soc Trop Med Hyg 91: 353-357.

Studier JA, Keppler KJ 1988. A note on the neighborjoining algorithm of Saitou and Nei. Mol Biol Evol 5: 729-731.

Swofford DL, Olsen GJ, Waddell PJ, Hillis DM 1996. Phylogenetic inference, p. 486-493. In DM Hillis, C Moritz, BK Mable (eds), Molecular Systematics, Sinauer Associates Inc., Massachusets, USA.

Van de Peer Y, De Wachter R 1994. TRECON for Windows: a software package for the construction and drawing of evolutionaty trees for the Microsoft Windows environment. Comput Applic Biosci 10: 569570.

Vidigal THDA, Neto ED, Carvalho OS, Simpson AJG 1994. Biomphalaria glabrata: Extensive genetic variation in Brazilian isolates revealed by random amplified polymorphic DNA analysis. Exper Parasitol 79: 187-194.

Vidigal THDA, Neto ED, Simpson AJG, Carvalho OS 1996. A low stringency polymerase chain reaction approach to identification of Biomphalaria glabrata and Biomphalaria tenagophila intermediate snail hosts of Schistosoma mansoni in Brazil. Mem Inst Oswaldo Cruz 91: 739-744.

Vidigal THDA, Spatz L, Nunes DN, Simpson AJG, Carvalho OS, Neto ED 1998. Biomphalaria spp: identification of the intermediate snail hosts of Schistosoma mansoni by polymerase chain reaction amplificatrion and restriction enzyme digestion of the ribossomal RNA gene intergenic spacer. Exper Parasitol 89: 180-187.

WHO-World Health Organization 1993. The control of schistosomiasis. Second report of the WHO expert committee. Technical Report Series Geneva, Switzerland, 830: 86. 
Molecular Identification of Biomphalaria - Roberta L Caldeira et al. 